\title{
PERAN MEDIASI REPUTASI PADA HUBUNGAN PENGUNGKAPAN CSR TERHADAP PROFITABILITAS BANK DI ASEAN DARI PERSPEKTIF GREEN BANKING
}

\author{
REZA ADITA ALDAMA \\ ELIADA HERWIYANTI \\ KIKY SRIREJEKI \\ Universitas Jenderal Soedirman, Jl. Prof. Dr. HR Boenyamin No.708, Purwokerto Utara, Banyumas, Jawa \\ Tengah, Indonesia \\ elly_idc@yahoo.com
}

\begin{abstract}
Indonesia there is a phenomenon where CSR reporting obligations have an impact on high levels of CSR reporting (quantity), but are not followed by extensive CSR disclosure (quality). This is certainly not in line with the existence of policies that require the disclosure of CSR for public companies in Indonesia, Thailand, and Singapore since 2012, 2014 and 2017. This study aims to determine the wide differences in CSR disclosure (CSRD) in Indonesia, Singapore, and Thailand and also the impact of CSRD with a reputation as a mediator to the profitability of banks in the three countries. The population in this study are banks listed on the Indonesia Stock Exchange, Singapore Stock Exchange, and Thailand Stock Exchange in 2017. The number of samples in this study were 50 banks. Based on the results of data analysis, it was concluded that: (1) There are differences in CSRD in the three countries, (2) CSRD has no effect on reputation (Tobin's Q), (3) Reputation has a positive effect on profitability (ROA), and (4) Reputation does not mediate the effect of CSRD on profitability because CSRD has no effect on reputation.
\end{abstract}

Keywords: Profitability, reputation, Tobin's Q, CSR

\begin{abstract}
Abstrak: Indonesia terjadi fenomena dimana kewajiban pelaporan CSR berdampak pada tingkat pelaporan CSR (kuantitas) yang tinggi, tetapi tidak diikuti dengan pengungkapan CSR yang luas (kualitas). Hal ini tentu tidak selaras dengan adanya kebijakan yang mewajibkan adanya pengungkapan CSR bagi perusahaan publik di Indonesia, Thailand, dan Singapura sejak tahun 2012, 2014, dan 2017. Penelitian ini bertujuan untuk mengetahui perbedaan luas pengungkapan CSR (CSRD) di Indonesia, Singapura, dan Thailand dan juga dampak CSRD dengan reputasi sebagai mediasi terhadap profitabilitas bank di ketiga negara tersebut. Populasi dalam penelitian ini adalah bank yang terdaftar di Bursa Efek Indonesia, Bursa Efek Singapura, dan Bursa Efek Thailand pada tahun 2017. Jumlah sampel dalam penelitian ini adalah 50 bank. Berdasarkan hasil analisis data, disimpulkan bahwa: (1) Terdapat perbedaan CSRD di ketiga negara, (2) CSRD tidak berpengaruh terhadap reputasi (Tobin's Q), (3) Reputasi berpengaruh positif terhadap profitabilitas (ROA), dan (4) Reputasi tidak memediasi pengaruh CSRD terhadap profitabilitas karena CSRD tidak berpengaruh terhadap reputasi.
\end{abstract}

Kata kunci: Profitabilitas, reputasi, Tobin's Q, CSR 


\section{PENDAHULUAN}

Fenomena kerusakan lingkungan, perubahan iklim, kemiskinan, dan kesenjangan sosial dibahas dalam Konferensi PBB pada tahun 2012. Dalam konferensi tersebut, para pemimpin negara menyepakati suatu konsep yang bertujuan untuk mewujudkan pembangunan berkelanjutan guna mengatasi berbagai krisis lingkungan dan sosial yang sedang terjadi. Konsep tersebut dinamakan green economy (Allen dan Clouth 2012). Salah satu konsep penting dari green economy adalah socially responsible investment (SRI), yaitu konsep yang menuntut investor untuk ikut melibatkan etika dan moral dalam pengambilan keputusannya (DLH 2013). Oleh karena itu, investor perlu untuk menganalisis data keberlanjutan yang dimiliki oleh perusahaan seperti pengungkapan corporate social responsibility (CSR)-nya.

Pengungkapan CSR telah diwajibkan bagi perusahaan publik di Indonesia, Thailand, dan Singapura mulai tahun 2012, 2014, dan 2017 (Loh et al. 2016). Kewajiban tersebut kemudian berdampak pada tingkat pelaporan yang sangat tinggi di Indonesia. Survei KPMG pada tahun 2015 menemukan bahwa Indonesia termasuk salah satu dari delapan negara di dunia yang memiliki tingkat pelaporan CSR di atas $90 \%$.
Tingkat pelaporan CSR tersebut lebih tinggi daripada Singapura dan Thailand yang memiliki tingkat pelaporan sebesar 84\% dan 67\% (KPMG 2015, 2017). Akan tetapi, tingginya tingkat pelaporan CSR tersebut tidak diikuti dengan luasnya pengungkapan CSR di Indonesia. Publikasi hasil penelitian oleh ASEAN CSR Network dengan National University of Singapore (NUS) pada tahun 2015 menunjukkan bahwa luas pengungkapan CSR di Malaysia $(47,7 \%)$ dan Indonesia $(48,4 \%)$ lebih rendah daripada Singapura $(48,8 \%)$ dan Thailand $(56,8 \%)$. Selanjutnya, pengungkapan CSR di Indonesia juga lebih rendah daripada Malaysia, Singapura, dan Thailand dalam kategori tata kelola dan lingkungan (Loh et al. 2016). Publikasi penelitian tersebut juga sesuai dengan hasil penelitian oleh Supriyono dan Suhardjanto (2013) serta Rahmawati dan Budiwati (2018) yang menemukan luas pengungkapan CSR dalam kategori sosial dan lingkungan di Indonesia lebih rendah daripada Thailand.

Rendahnya angka luas pengungkapan CSR di Indonesia mengindikasikan rendahnya transparansi dan tanggung jawab perusahaanperusahaan di Indonesia atas dampak bisnisnya terhadap krisis sosial dan lingkungan yang sedang terjadi. UNESCAP (2017) dalam Philp et al. (2018) sendiri menyatakan bahwa ASEAN

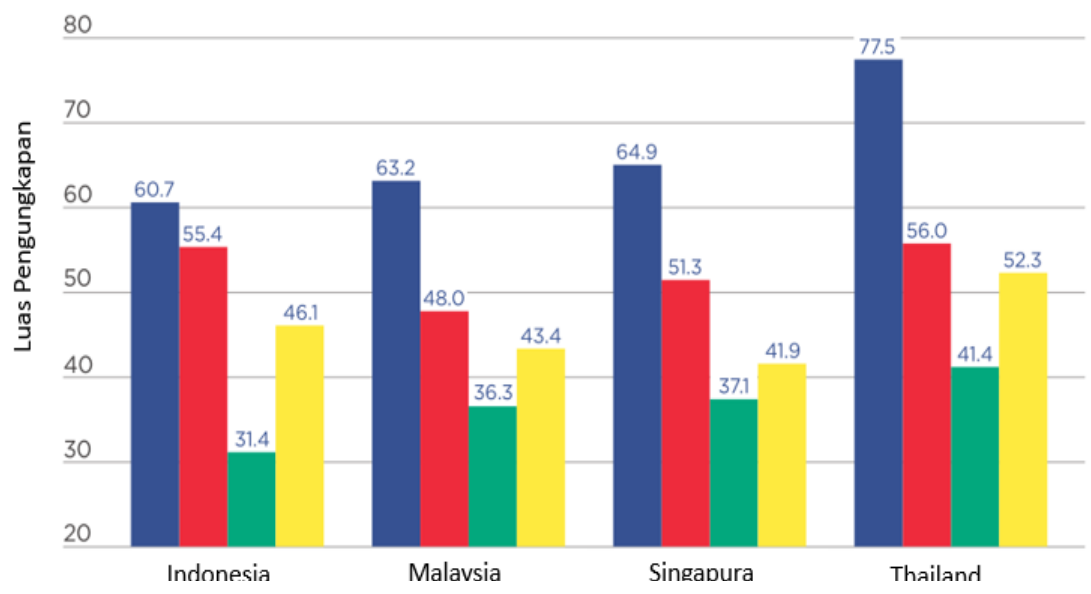

Gambar 1 Luas Pengungkapan CSR Perusahaan di ASEAN (Loh et al., 2016) 
sedang mengalami hambatan dalam mewujudkan pembangunan berkelanjutan karena pembabatan hutan yang masih marak dilakukan. Maraknya pembabatan hutan tersebut juga telah menjadikan Indonesia menduduki peringkat pertama se-ASEAN dan kelima sebagai penyumbang emisi gas rumah kaca terbesar di dunia (Chrysolite et al. 2017). Akibatnya, Parlemen Uni Eropa mengeluarkan resolusi yang melarang penggunaan minyak sawit pada bahan bakar nabati (biofuel) mulai tahun 2020 (Tan dan Maulia 2017). Selain itu, Iceland Foods Ltd (perusahaan ritel asal Inggris) juga telah menghentikan penjualan produk yang mengandung minyak sawit karena banyaknya degradasi lahan yang diakibatkan deforestasi oleh perusahaan sawit (The Jakarta Post 2018).

Berbagai sanksi yang merugikan perekonomian Indonesia tidak akan terjadi jika perusahaan sawit didorong untuk lebih bertanggung jawab atas dampak bisnisnya. Untuk mewujudkannya, pemerintah dapat menerapkan green economy dalam perbankan Indonesia dengan konsep green banking.

Green banking adalah salah satu upaya oleh pemerintah dalam mengubah paradigma pembangunan nasional dari sistem greedy economy yang berfokus pada pertumbuhan ekonomi (profit) semata menjadi green economy yang berfokus pada konsep dasar pembangunan berkelanjutan, yaitu keseimbangan dari 3P (profit, people dan planet)

(KLH 2014). Dalam mewujudkan pembangunan berkelanjutan tersebut, bank sebagai lembaga intermediasi keuangan mempunyai peran strategis karena memiliki kemampuan untuk memengaruhi berbagai stakeholder dalam perekonomian melalui alokasi dana yang dilakukannya pada berbagai aktivitas ekonomi (Perbanas 2009).

Salah satu contoh penerapan green banking dalam perbankan Indonesia adalah regulasi PBI No. 14/15/PBI/2012. Regulasi tersebut mewajibkan setiap bank untuk memperhatikan upaya yang dilakukan debitur dalam rangka memelihara lingkungan hidup (pro-planet). Untuk menerapkannya, bank diperlukan untuk memperhatikan hasil Program Penilaian Peringkat Kinerja Perusahaan (Proper) yang dikeluarkan Kementerian Lingkungan Hidup dan Kehutanan (KLHK) ketika menilai kualitas kredit maupun mempertimbangkan permohonan perusahaan sawit yang menjadi calon debiturnya (Paino 2015). Selain itu, juga terdapat PBI No. 14/22/PBI/2012 dengan revisinya PBI No. 17/12/PBI/2015 yang menuntut bank untuk mempermudah akses kredit bagi usaha-usaha mikro, kecil, dan menengah (UMKM) dengan besaran minimal $20 \%$ dari total portofolio kreditnya mulai tahun 2018. Oleh karena itu, UMKM akan lebih berkembang dan mempekerjakan lebih banyak karyawan sehingga dapat mengatasi masalah kesenjangan sosial yang sedang terjadi (propeople).

Green banking sendiri dapat diterapkan melalui green finance, paperless banking, energy consciousness, mass transportation system, dan green building (Bahl 2012). Beberapa contoh bank di ASEAN yang telah melaporkan penerapan green banking, antara lain Bank Negara Indonesia 46 (BNI), Kasikornbank (Kbank), dan The Development Bank of Singapore (DBS). BNI menerapkan green banking melalui pelayanan perbankan berbasis lingkungan, seperti paperless, e-billing, e-banking, dan green finance, serta menolak permohonan pinjaman oleh perusahaan yang bertingkat Proper rendah (Aisyah dan Pujiyono 2016). Selanjutnya, Kbank juga menerapkannya melalui green finance, seleksi pendanaan proyek dengan ESG assestment, dan green building (Kbank 2017). DBS sendiri meluncurkan produk green bond yang digunakan untuk membiayai berbagai green projects (DBS 2017).

Penelitian terdahulu tentang perbandingan luas pengungkapan CSR atau kondisi penerapan green banking di Indonesia dengan negara ASEAN lainnya belum banyak ditemukan. Oleh karena itu, penelitian ini 
bertujuan untuk mengetahui perbedaan luas pengungkapan CSR antara bank-bank di Indonesia, Singapura, dan Thailand sehingga dapat diketahui gambaran umum dari penerapan green banking di ASEAN melalui pengungkapan CSR dalam laporan tahunan dan/atau laporan keberlanjutan oleh bank.

Investor yang telah membandingkan pengungkapan CSR pada berbagai bank di ASEAN seharusnya dapat menilai lebih baik reputasi bank yang menerapkan green banking dan akan mendukung bank tersebut dengan meningkatkan nilai sahamnya. Hal tersebut terjadi karena investor menggunakan pertimbangan etika dan moral dalam keputusannya sesuai dengan konsep SRI. Akan tetapi, banyak penelitian masih menemukan hasil yang beragam atas hal tersebut. Oleh karena itu, penelitian ini juga bertujuan untuk mengetahui pengaruh luas pengungkapan CSR (CSRD) dengan reputasi sebagai mediasi terhadap profitabilitas bank. Sari dan Priantinah (2018) menemukan bahwa CSRD tidak berpengaruh terhadap nilai perusahaan sektor perbankan di BEl pada periode 2011-2015. Sebaliknya, Kapita dan Suardana (2018) menemukan bahwa CSRD berpengaruh positif terhadap reputasi perusahaan manufaktur di BEI pada periode 2014-2016 karena perusahaan telah mengomunikasikan CSR-nya secara tepat. Hal yang sama ditemukan oleh Sari et al. (2016) pada perusahaan multinasional di Malaysia. Akan tetapi, Sari et al. (2016) juga menemukan bahwa CSRD dapat berpengaruh negatif terhadap nilai perusahaan multinasional di Indonesia karena shareholders menganggap CSR hanya membebani perusahaan dan mengurangi dividennya.

Saeednia dan Sohani (2013) dan Taghian et al. (2015) menemukan bahwa reputasi tidak memediasi langsung pengaruh CSR terhadap kinerja keuangan, melainkan melalui mediasi seperti kepuasan konsumen dan pangsa pasar. Hal tersebut terjadi karena CSR terlebih dahulu berpengaruh langsung terhadap persepsi stakeholders melalui kegiatan pemasaran sebelum kemudian berdampak pada profitabilitas perusahaan (Taghian et al. 2015). Sebaliknya, Galbreath dan Shum (2012) serta Saeidi et al. (2015) menemukan bahwa reputasi dapat memediasi langsung pengaruh CSR terhadap kinerja keuangan.

Penelitian ini mengacu pada penelitian Sari et al. (2016) yang membandingkan CSRD dari perusahaan multinasional di Indonesia dan Malaysia dan meneliti dampaknya terhadap nilai perusahaan (Tobin's Q) dan kinerja keuangan (ROA). Berbeda dengan Sari et al. (2016), penelitian ini menambahkan variabel reputasi sebagai variabel mediasi karena diasumsikan CSR tidak dapat secara langsung berpengaruh terhadap kinerja keuangan (Saeidi et al. 2015). Variabel mediasi diukur dengan Tobin's $Q$ karena diasumsikan investor akan mendukung bank dengan reputasi yang baik dengan memberikan prioritas dan premi dalam pembelian sahamnya. Selain itu, pengaruh luas pengungkapan CSR dianalisis secara bersamaan di Indonesia, Singapura, dan Thailand agar diketahui secara umum dari pengaruh luas pengungkapan CSR terhadap reputasi sebagai mediasi dan profitabilitas bank di ASEAN.

\section{Teori Stakeholders}

Freeman et al. (2010) mendefinisikan pemangku kepentingan atau stakeholders sebagai berbagai kelompok atau individu yang dapat memengaruhi atau terpengaruh oleh realisasi tujuan perusahaan. Akan tetapi, setiap stakeholder tersebut dapat memiliki harapan yang berbeda tentang perusahaan (Venkataraman 1999). Oleh karena itu, berbagai harapan stakeholders tersebut harus diseimbangkan karena masing-masing stakeholder mempunyai pengaruh terhadap ketersediaan sumber daya ekonomi yang digunakan untuk mendukung aktivitas bisnis perusahaan. Salah satu caranya adalah perusahaan perlu membentuk komunikasi yang 
terbuka dan meningkatkan interaksi dalam merespons berbagai tuntutan stakeholders-nya (Freeman et al. 2010).

\section{Teori Signalling}

Spence (2002) dalam Connelly et al. (2011) menyatakan bahwa teori signalling berhubungan pada usaha-usaha yang dilakukan untuk mengurangi asimetri informasi. Asimetri informasi terjadi ketika individu yang berbeda mengetahui tingkatan informasi yang berbeda atas sesuatu karena sebagian informasi dirahasiakan oleh individu yang mengetahuinya terhadap pengambil keputusan yang memerlukan informasi tersebut. Secara umum, manajer perusahaan mempunyai informasi yang tidak dimiliki oleh investor. Oleh karena itu, manajer perlu memberikan sinyal kepada stakeholders melalui berbagai pengungkapan informasi tentang aktivitas bisnis perusahaan. Akibatnya, asimetri informasi yang ada di antara manajer dan investor akan berkurang sehingga dapat meningkatkan nilai dan reputasi perusahaannya (Kapita dan Suardana 2018).

\section{Corporate Social Responsibility Disclosure}

Undang-Undang Perseroan Terbatas

No. 40 Tahun 2007 mendefinisikan konsep Corporate Social Responsibility (CSR) sebagai komitmen perusahaan untuk berperan serta dalam pembangunan ekonomi berkelanjutan guna meningkatkan kualitas kehidupan dan lingkungan yang bermanfaat bagi perusahaan tersebut, komunitas lokal, dan masyarakat pada umumnya. Oleh karena itu, perusahaan berperan untuk menyelesaikan masalah sosial dan lingkungan yang sedang terjadi dalam strategi dan operasi bisnisnya. Konsep CSR juga dapat berhubungan dengan socially responsible investment (SRI), salah satu konsep dari green economy, karena keduanya mempertimbangkan aspek etika, sosial, dan lingkungan dalam hubungannya dengan shareholders (Paluszak dan WiśniewskaPaluszak 2016). Selanjutnya, CSR perlu untuk diungkapkan guna mengkomunikasikan aktivitas CSR yang telah dilakukan kepada stakeholders (Sari et al. 2016).

GRI (2019) mendefinisikan pengungkapan CSR atau Corporate Social Responsibility Disclosure (CSRD) sebagai pengungkapan oleh perusahaaan tentang dampak ekonomi, lingkungan, dan sosial yang disebabkan oleh aktivitas bisnisnya. Pengungkapan tersebut biasanya tersedia dalam laporan tahunan (annual report) dan/atau laporan berkelanjutan (sustainability report) yang diterbitkan setiap tahun oleh perusahaan. Selain itu, pengungkapan CSR tersebut dapat disusun dengan rerangka pelaporan seperti GRI.

\section{Reputasi}

Fombrun dan van Riel (1997) mendefinisikan reputasi perusahaan sebagai persepsi publik atas aktivitas perusahaan di masa lalu dan prospeknya di masa datang yang dibandingkan dengan perusahaan sejenis atau pesaingnya. Salah satu aktivitas tersebut adalah CSR (Yadaf et al. 2018). Reputasi perusahaan dapat memberikan banyak manfaat, seperti membentuk preferensi terhadap produk, menarik dukungan kepada perusahaan dalam situasi kontroversial, dan menjadi nilai perusahaan (Hardjana 2005). Oleh karena itu, kinerja yang baik dapat mengindikasikan bahwa perusahaan memiliki reputasi yang baik.

Salah satu rasio kinerja perusahaan yang dapat mengukur nilai atau reputasi perusahaan adalah Tobin's $Q$ (Kapita dan Suardana 2018). Jika nilai Tobin's $Q>1,00$ maka saham perusahaan tergolong overvalued atau harga pasarnya lebih mahal daripada nilai bukunya (Ali et al. 2016). Oleh karena itu, semakin besar nilai Tobin's $Q$ maka semakin baik reputasi perusahaan karena semakin besar dukungan investornya (Sukamulja 2005).

\section{Profitabilitas}

Rasio profitabilitas adalah sekelompok rasio yang menunjukkan kombinasi dari pengaruh likuiditas, manajemen aset, dan utang 
terhadap hasil operasi (Brigham dan Houston 2010). Salah satu contoh rasio profitabilitas adalah Return on Assets (ROA). Rasio profitabilitas digunakan untuk mengetahui kemampuan perusahaan dalam menghasilkan laba selama periode tertentu sehingga mencerminkan kemampuan manajemen dalam mengelola perusahaannya (Sari et al. 2016). Selain itu, ROA juga dapat digunakan untuk menilai kesehatan bank. Standar ROA yang terbaik untuk bank adalah di atas 1,5\% (Setiawan 2017).

\section{Perbandingan Luas CSRD oleh Bank di Indonesia, Singapura, dan Thailand Pemerintah Indonesia dapat} menerapkan green economy pada sistem perbankan dengan konsep green banking untuk mewujudkan pembangunan berkelanjutan di Indonesia. Green banking mengubah paradigma pembangunan nasional dari sistem greedy economy menjadi green economy yang berfokus pada keseimbangan dari 3P (profit, people dan planet) (KLH 2014). Beberapa contoh penerapan green banking, antara lain green finance, paperless banking, energy consciousness, mass transportation system, dan green building (Bahl 2012). Selanjutnya, berbagai penerapan green banking tersebut biasanya dilaporkan dengan pengungkapan CSR oleh bank dalam laporan tahunan dan/atau laporan keberlanjutannya.

Berdasarkan teori stakeholders dan signalling, pengungkapan CSR atau Corporate Social Responsibility Disclosure (CSRD) didorong oleh tuntutan berbagai pemangku kepentingan (stakeholder) untuk melaksanakan dan melaporkan CSR-nya. Hal tersebut dilakukan agar dapat mengurangi asimetri informasi mengenai tanggung jawab perusahaan atas dampak ekonomi, lingkungan, dan sosial yang disebabkan oleh aktivitas bisnisnya. Walaupun begitu, tuntutan berupa kewajiban pelaporan CSR hanya berdampak pada tingginya tingkat pelaporan CSR (kuantitas) dan tidak diikuti dengan luasnya pengungkapan CSR (kualitas) di Indonesia (Loh et al. 2016). Penelitian oleh Supriyono dan Suhardjanto (2013) serta Rahmawati dan Budiwati (2018) juga menemukan bahwa CSRD dalam kategori sosial dan lingkungan di Indonesia lebih rendah daripada di Thailand. Sebaliknya, Chapple dan Moon (2005) belum menemukan adanya perbedaan CSR di Indonesia dan Thailand. Akan tetapi, Indonesia memiliki hasil terburuk di antara 7 (tujuh) negara Asia dengan $73 \%$ perusahaan yang melaporkan CSR-nya memiliki CSRD dalam kategori minimal. Berdasarkan uraian di atas, maka hipotesis yang diajukan adalah sebagai berikut:

$\mathrm{H}_{1}$ Terdapat perbedaan luas CSRD oleh bank di Indonesia, Singapura, dan Thailand.

\section{Pengaruh Luas CSRD terhadap Reputasi Bank}

Berdasarkan teori stakeholders dan teori signalling, pengungkapan CSR bertujuan untuk memenuhi berbagai tuntutan stakeholders dan memberikan sinyal kepada mereka bahwa perusahaan telah berkinerja secara baik. Pengungkapan CSR tersebut menunjukkan transparansi dan tanggung jawab perusahaan atas aktivitas bisnisnya (Loh et al. 2016). Oleh karena itu, CSR dapat membentuk reputasi karena memengaruhi bagaimana stakeholders menilai perusahaan dengan membandingkannya terhadap pesaingnya (Taghian et al. 2015).

Uraian teori di atas juga didukung dengan hasil penelitian Sari et al. (2016) serta Kapita dan Suardana (2018) yang menemukan bahwa CSRD berpengaruh positif terhadap nilai perusahaan atau reputasinya. Sebaliknya, Saeednia dan Sohani (2013) menemukan bahwa CSR tidak berpengaruh langsung terhadap reputasi, melainkan melalui variabel mediasi kepuasan konsumen pada Bank Saderat Iran. Berdasarkan uraian di atas, maka hipotesis yang diajukan adalah sebagai berikut: 
$\mathrm{H}_{2} \quad$ CSRD berpengaruh positif terhadap nilai perusahaan atau reputasi bank.

\section{Pengaruh Reputasi Bank terhadap Profitabilitas}

Berdasarkan teori signalling, manajer mengungkapkan informasi mengenai perusahaannya agar diketahui bahwa perusahaan yang dikelolanya telah berkinerja lebih baik daripada perusahaan lainnya (Kapita dan Suardana 2018). Pengungkapan informasi tersebut kemudian membentuk persepsi stakeholders atas perusahaannya sehingga terbentuk suatu reputasi. Reputasi tersebut kemudian memengaruhi bagaimana stakeholders menilai perusahaan dengan membandingkannya terhadap pesaingnya (Taghian et al. 2015).

Berdasarkan teori stakeholders, berbagai stakeholder dengan sumber daya ekonomi yang dikuasainya akan mendukung perusahaan yang memenuhi tuntutan mereka, yaitu tuntutan agar bank memiliki reputasi yang baik. Helm (2007) menyatakan bahwa investor menganggap perusahaan yang memiliki reputasi baik memiliki risiko yang lebih kecil daripada yang tidak memiliki reputasi baik. Selain itu, stakeholder seperti konsumen juga akan menyalurkan dananya untuk membeli produk dan jasa perusahaan yang memiliki reputasi baik (Sari et al. 2016). Reputasi bank yang terbentuk dari CSR sendiri telah diketahui dapat memengaruhi profitabilitasnya melalui peningkatan pendapatan bunga dan non-bunga serta penurunan biaya overhead (Shen et al., 2016). Oleh karena itu, reputasi bank yang baik akan dapat meningkatkan profitabilitasnya.

Uraian teori di atas didukung dengan hasil penelitian Saeidi et al. (2015) yang menemukan bahwa reputasi perusahaan berpengaruh positif terhadap kinerja keuangannya. Sebaliknya, Taghian et al. (2015) menemukan bahwa reputasi berpengaruh tidak langsung terhadap profitabilitas, melainkan melalui variabel mediasi pangsa pasar di Australia. Hal tersebut terjadi karena reputasi dari CSR hanya berpengaruh langsung terhadap persepsi konsumen melalui berbagai kegiatan pemasaran yang kemudian berpengaruh tidak langsung terhadap profitabilitasnya (Taghian et al. 2015).

Bank sendiri menerapkan CSR atau green banking secara langsung melalui produknya atau tanpa kegiatan pemasaran yang diharapkan untuk memperluas pangsa pasar atau meningkatan dana pihak ketiganya. Hal tersebut terjadi karena nasabah bersedia membayar premi atas produk bank yang memiliki reputasi baik (Kim et al. 2010 dalam Shen et al. 2016). Oleh karena itu, reputasi bank diasumsikan dapat memengaruhi profitabilitasnya secara langsung. Berdasarkan uraian di atas, maka hipotesis yang diajukan adalah sebagai berikut:

$\mathrm{H}_{3}$ Reputasi bank berpengaruh positif terhadap profitabilitas.

\section{Mediasi Reputasi Bank pada Pengaruh Luas CSRD terhadap Profitabilitas}

Berdasarkan teori stakeholders, pengungkapan CSR atau Corporate Social Responsibility Disclosure (CSRD) didorong oleh tuntutan untuk merespons keinginan pemangku kepentingan (stakeholder) bank seperti investor. Tuntutan tersebut terbentuk karena investor sendiri dituntut untuk melibatkan pertimbangan etika dan moral dalam keputusan investasinya (DLH 2013). Untuk melakukannya, investor perlu menganalisis data keberlanjutan bank seperti pengungkapan CSR-nya.

Berdasarkan teori signalling, pengungkapan CSR dapat mengurangi asimetri informasi antara manajemen dan investor mengenai tanggung jawab bank atas aktivitas bisnisnya. Semakin luas pengungkapan CSR yang dilakukan maka semakin kecil asimetri informasi yang ada. Asimetri yang kecil menunjukkan transparansi dan tanggung jawab oleh bank sehingga stakeholders menilai lebih baik bank tersebut jika dibandingkan dengan pesaingnya. Akibatnya, reputasi yang baik akan terbentuk dan investor menganggap bank 
tersebut memiliki risiko yang lebih kecil daripada pesaingnya sehingga bersedia membayar premi atas sahamnya (Helm 2007).

Banyak penelitian telah menemukan CSR secara langsung berpengaruh positif terhadap kinerja keuangan, tetapi beberapa penelitian lainnya menemukan pengaruh negatif atau netral. Penelitian tersebut tidak membahas secara jelas bagaimana CSR dapat berpengaruh positif, netral, atau negatif terhadap kinerja keuangan. Oleh karena itu, variabel mediasi dan moderasi diperlukan dalam analisis pengaruh CSR terhadap kinerja keuangan (Branco dan Rodrigues 2006 dalam Saeidi et al. 2015). Galbreath dan Shum (2012) menemukan bahwa CSR tidak berpengaruh langsung terhadap kinerja keuangan, melainkan melalui variabel mediasi kepuasan konsumen dan reputasi. Hal yang sama ditemukan oleh Saeidi et al. (2015) yang menggunakan variabel mediasi keunggulan kompetitif dan reputasi yang dipengaruhi oleh kepuasan konsumen.

Reputasi bank dalam penelitian ini diukur dengan rasio kinerja saham perusahaan, yaitu Tobin's $Q$ sehingga lebih fokus pada sebagian stakeholders terutama investor. Selain itu, penelitian ini juga berfokus pada dampak luas pengungkapan CSR (CSRD) terhadap investor yang diasumsikan membaca CSRD dalam laporan tahunan dan/atau laporan keberlanjutan oleh bank. Oleh karena itu, kepuasan pelanggan tidak perlu diukur dan reputasi dari investor sendiri diasumsikan telah cukup untuk mengetahui peran mediasi reputasi pada pengaruh luas CSRD terhadap profitabilitas bank. Berdasarkan uraian di atas, maka hipotesis yang diajukan adalah sebagai berikut:

$\mathrm{H}_{4}$ Reputasi bank memediasi pengaruh luas CSRD terhadap profitabilitas.

\section{METODE PENELITIAN}

Jenis penelitian ini adalah penelitian kuantitatif dengan data sekunder yang dikumpulkan pada satu waktu atau crosssectional pada subjek yang berbeda. Selanjutnya, penelitian ini membandingkan data dari suatu variabel (komparatif) dan menguji hubungannya dengan data dari variabel lainnya (asosiatif). Jenis data penelitian ini adalah data sekunder. Data-data yang diperoleh pada penelitian ini kemudian dianalisis dengan software IBM SPSS Statistics 25.

\section{Populasi dan Sampel}

Populasi penelitian ini adalah perusahaan sektor keuangan sub sektor bank (bank) yang terdaftar pada Bursa Efek Indonesia (BEI), Bursa Efek Singapura (BES), dan Bursa Efek Thailand (BET) pada tahun 2017. Sampel dipilih dengan metode purposive sampling, yaitu populasi yang dijadikan sampel adalah yang memenuhi kriteria-kriteria tertentu. Kriteria pertama yaitu bank yang terdaftar pada $\mathrm{BEI}$, BES, dan BET pada tahun 2017. Kriteria kedua yaitu menyediakan laporan tahunan dan atau laporan keberlanjutan secara online. Kriteria ketiga yaitu data terkait variabel-variabel yang diteliti tersedia dengan lengkap. Dengan kriteria tersebut pada akhirnya ditemukan jumlah sampel akhir adalah 50 perusahaan.

Teknik pengumpulan data dalam penelitian ini menggunakan metode dokumentasi. Data variabel-variabel penelitian ditelusuri dalam laporan tahunan, laporan berkelanjutan, dan/atau data harga saham historis pada tahun 2017 yang diperoleh dari website Bursa Efek Indonesia (BEI) melalui www.idx.co.id, Bursa Efek Singapura (BES) melalui www.sgx.com, dan Bursa Efek Thailand (BET) melalui www.set.or.th.

Variabel dependen dalam penelitian ini adalah kinerja keuangan yang diukur melalui profitabilitas. Rasio profitabilitas adalah sekelompok rasio yang menunjukkan kombinasi dari pengaruh likuiditas, manajemen aset, dan utang pada hasil operasi (Brigham dan Houston 2010). Rasio profitabilitas mencerminkan kemampuan manajemen dalam mengelola perusahaannya yang dapat diukur dengan Return On Assets (ROA) (Sari 
et al. 2016). ROA juga dapat digunakan untuk menilai kesehatan bank. ROA dalam Lampiran Surat Edaran Bank Indonesia No. 13/24/DPNP dihitung dengan rumus:

$$
\text { ROA }=\frac{\text { Laba Sebelum Pajak }}{\text { Rerata Total Aset }}
$$

Variabel mediasi dalam penelitian ini adalah reputasi bank. Salah satu aktivitas perusahaan yang dapat meningkatkan reputasi suatu perusahaan adalah CSR (Yadaf et al. 2018). Pengungkapan dari aktivitas CSR tersebut kemudian memberikan dampak pada shareholders dalam proses pengambilan keputusan investasinya (Sari et al. 2016).

Reputasi bank dapat diukur menggunakan rasio Tobin's $Q$. Tobin's $Q$ membandingkan nilai pasar ekuitas dengan nilai buku aset perusahaan. Oleh karena itu, semakin besar nilai Tobin's $Q$ maka semakin baik reputasi perusahaan karena semakin besar dukungan investor untuk perusahaan tersebut (Kapita dan Suardana 2018). Berikut adalah rumus Tobin's $Q$ menurut Smithers dan Wright (2007) dalam Kapita dan Suardana (2018):

$$
R E P=\frac{E M V+D}{A B V+D}
$$

Keterangan:

EMV = Jumlah saham biasa yang beredar dikali dengan harga penutupan saham (closing price) di akhir periode

$\mathrm{ABV}=$ Nilai buku aset di akhir periode

$\mathrm{D}=$ Nilai buku liabilitas di akhir periode

Variabel independen yang digunakan dalam penelitian ini adalah luas pengungkapan CSR atau Corporate Social Responsibility Disclosure (CSRD). Pengungkapan CSR yang dilakukan oleh perusahaan bertujuan untuk mengkomunikasikan aktivitas CSR yang telah dilakukannya kepada stakeholders (Sari et al. 2016). Variabel CSRD merupakan variabel yang terdiri dari 91 item berdasarkan GRI 4 yang diukur seperti variabel dummy dengan metode content analysis. Berikut adalah rumus CSRD menurut Haniffa dan Cooke (2005):

$$
\text { CSRD }=\frac{\text { Skor Pengungkapan CSR }}{91}
$$

Hipotesis-hipotesis dalam penelitian ini diuji dengan Ordinary Least Square (OLS) pada dua persamaan regresi yang digunakan, yaitu:

Persamaan 1: REP $=\alpha+\beta 1$ CSRD $+e$

Persamaan 2: ROA $=\alpha+\beta 1$ CSRD $+\beta 2$ REP

$$
+\mathrm{e}
$$

HASIL

Sebanyak 5 (lima) data outlier dideteksi dengan diagram boxplot. Untuk kepentingan analisis, data outlier tersebut kemudian diekslusikan dari analisis data karena nilainya dianggap berasal dari kejadian yang jarang. Oleh karena itu, analisis statistik deskriptif setelah menghilangkan outlier $(n=50)$ adalah sebagai berikut:

\section{Tabel 1 Analisis Statistik Deskriptif}

\begin{tabular}{ccccc}
\hline Variabel & Min. & Maks. & Mean & $\begin{array}{c}\text { Std. } \\
\text { Deviasi }\end{array}$ \\
\hline $\operatorname{CSRD}\left(\mathrm{X}_{1}\right)$ & 0,03297 & 0,70303 & 0,19077 & 0,12281 \\
\hline $\operatorname{REP}\left(\mathrm{X}_{2}\right)$ & 0,48056 & 0,84591 & 0,58092 & 0,07357 \\
\hline $\operatorname{ROA}(\mathrm{Y})$ & $-0,01547$ & 0,04086 & 0,01423 & 0,01093 \\
\hline
\end{tabular}

Pemusatan data dengan nilai mean dari luas pengungkapan CSR (CSRD) adalah sebesar 0,19077 (19\%) atau mendekati nilai minimum $(3 \%)$ dan sangat menjauhi nilai maksimumnya (70\%). Hal tersebut disebabkan karena sebagian besar sampel penelitian berasal dari Indonesia, yaitu 36 dari 50 bank memiliki nilai mean dari CSRD sebesar 0,1510 (15\%). Nilai CSRD di Indonesia tersebut lebih rendah daripada sampel yang berasal dari Singapura dan Thailand dengan nilai mean sebesar 0,29304 (29\%) dan 0,29270 (29\%). Selain itu, nilai maksimum CSRD sebesar $70 \%$ oleh Bangkok Bank (BBL) juga memiliki nilai 
yang jauh lebih tinggi daripada nilai mean secara keseluruhan.

Nilai maksimum dari reputasi (Tobin's Q) adalah 0,84591 atau lebih kecil dari 1. Hal tersebut berarti sampel bank secara keseluruhan memiliki harga saham yang undervalued atau nilai sahamnya lebih kecil daripada asetnya. Selanjutnya, nilai mean dari ROA adalah $1,4 \%$ atau sedikit lebih kecil daripada 1,5\%. Hal tersebut berarti secara umum bank-bank di ketiga negara memiliki ROA yang baik atau sehat pada tahun 2017.

Tabel 2

Analisis Statistik Deskriptif (Mean) - CSRD dalam Kategori

\begin{tabular}{|c|c|c|c|c|c|c|c|}
\hline \multicolumn{5}{|c|}{ Gurtory } & \multirow{2}{*}{\multicolumn{3}{|c|}{ Nilai $\operatorname{sig} .=0,001^{*}$}} \\
\hline & Indonesia & Singapura & Thailand & & & & \\
\hline Kategorı & $(\mathrm{N}=36)$ & $(\mathrm{N}=3)$ & $(\mathrm{N}=11)$ & Mean & \multicolumn{3}{|c|}{ Tabel 4 Uji Mann-Whitney } \\
\hline Ekonomi (EC) & 0,30247 & 0,48148 & 0,38388 & $0,38926-$ & Grup & $\mathrm{N}$ & Mean Rank \\
\hline Lingkungan (EN) & 0,07435 & 0,30392 & 0,24332 & 0,20719 & \multicolumn{3}{|l|}{ Perbandingan ke-1: } \\
\hline Sosial (SOS) & 0,17708 & 0,25000 & 0,31061 & 0,24590 & Indonesia & 36 & 18,76 \\
\hline & & & & & Singapura & 3 & 34,83 \\
\hline
\end{tabular}

Berdasarkan pada tabel di atas, maka dapat diketahui bahwa CSRD di ketiga negara dalam kategori lingkungan (21\%) lebih rendah daripada kategori sosial $(25 \%)$ dan ekonominya (39\%). Hal tersebut disebabkan karena CSRD dalam kategori lingkungan (7\%) di Indonesia yang jauh lebih rendah daripada di Singapura $(30 \%)$ dan Thailand (24\%). Selain itu, CSRD dalam kategori ekonomi dan sosial di Indonesia (30\% dan 18\%) juga lebih rendah daripada Singapura (48\% dan $25 \%$ ), dan Thailand (38\% dan 31\%). Oleh karena itu, dapat disimpulkan bahwa CSRD dalam semua kategori (ekonomi, lingkungan, dan sosial) oleh bank-bank di Indonesia masih relatif lebih rendah daripada Singapura dan Thailand.

Uji Kruskal-Wallis (K-W) digunakan untuk mengetahui apakah ada perbedaan antara pengungkapan CSR (CSRD) oleh bankbank yang terdaftar di Bursa Efek Indonesia (BEI), Bursa Efek Singapura (BES), dan Bursa Efek Thailand (BET) pada tahun 2017. Jika hasil uji K-W menunjukkan nilai asymp. sig. < 0,05 maka dapat disimpulkan bahwa hipotesis nol (Ho) ditolak sehingga dilakukan post hoc test dengan uji Mann-Whitney (M-W) untuk mengetahui letak perbedaannya. Jika hasil uji M-W menunjukkan nilai asymp. sig. < 0,05 maka dapat disimpulkan bahwa ada perbedaan CSRD di kedua negara yang sedang dibandingkan.

Tabel 3 Uji Kruskal-Wallis

\begin{tabular}{clll}
\hline Grup & N & $\begin{array}{c}\text { Mean } \\
\text { Rank }\end{array}$ \\
\hline CSRD & Indonesia & 36 & 20,75 \\
\hline Singapura & 3 & 41,50 \\
\hline Thailand & 11 & 36,68 \\
\hline
\end{tabular}

\begin{tabular}{l} 
Nilai Kruskal-Wallis $=13,936$ \\
\hline Nilai sig. $=\mathbf{0 , 0 0 1 ^ { * }}$
\end{tabular}

Tabel 4 Uji Mann-Whitney

Nilai Mann-Whitney $=9,500$

Nilai $\operatorname{sig} .=0,019^{*}$

Perbandingan ke-2:

\begin{tabular}{cccc} 
CSRD & Indonesia & 36 & 20,49 \\
\hline Thailand & 11 & 35,50 \\
\hline
\end{tabular}

Nilai Mann-Whitney $=71,500$

Nilai sig. $=0,001^{*}$

Perbandingan ke-3:

$\begin{array}{llll}\text { CSRD Singapura } 3 & 8,67\end{array}$

Thailand $\quad 11 \quad 7,18$

Nilai Mann-Whitney $=13,000$

Nilai sig. $=0,585$

Uji statistik t digunakan untuk menguji tingkat signifikansi luas pengungkapan CSR (CSRD) terhadap reputasi (LG10_REP), reputasi (LG10_REP) terhadap ROA, dan CSRD terhadap ROA. Jika nilai sig. $<0,05$ maka dapat disimpulkan bahwa hipotesis nol $(\mathrm{Ho})$ 
ditolak atau variabel independen berpengaruh signifikan terhadap variabel dependen.

Tabel 5 Uji Statistik t

\begin{tabular}{|c|c|c|c|c|c|}
\hline & $\begin{array}{c}\text { Unstandarized } \\
\text { B }\end{array}$ & $\begin{array}{l}\text { Coefficients } \\
\text { Std. Error }\end{array}$ & $\begin{array}{l}\text { Standariz } \\
\text { ed } \\
\text { B }\end{array}$ & $\mathrm{t}$ & $\begin{array}{l}\text { juga menemukan bahwa ada perbedaan CSRD } \\
\text { di Indönesia dengan Singapura dan Thailand, }\end{array}$ \\
\hline \multicolumn{5}{|c|}{ Persamaan Regresi 1a: } & tetapi tidak ada perbedaan CSRD di Sinaap \\
\hline Constant & $-0,228$ & 0,014 & & $-16,784$ & da,04hoil \\
\hline CSRD & $-0,058$ & 0,060 & $-0,137$ & $-0,960$ & \\
\hline \multicolumn{5}{|c|}{ Persamaan Regresi $2^{\mathrm{b}}$ : } & stakeholders dan teori sig \\
\hline Constant & 0,026 & 0,007 & & 3,723 & \\
\hline CSRD & 0,028 & 0,012 & 0,314 & 2,362 & $0,0<2$ \\
\hline LG10_REP & 0,071 & 0,028 & 0,336 & 2,523 & dïnd,ưăsikan \\
\hline
\end{tabular}

a. Variabel Dependen: LG10_REP

b. Variabel Dependen: ROA

Pengujian efek mediasi memerlukan beberapa tahapan (causal steps) yang harus dipenuhi, yaitu terdapat pengaruh signifikan dari variabel independen terhadap variabel mediasi ( $\mathrm{Ho}^{2}$ ditolak) dan variabel mediasi terhadap variabel dependen ( $\mathrm{Ho}^{3}$ ditolak). Jika salah satu tahapan tersebut tidak terpenuhi maka pengujian efek mediasi tidak perlu dilakukan dan dapat disimpulkan bahwa tidak ada mediasi atau pengaruh tidak langsung oleh variabel mediasi dari variabel independen terhadap variabel dependen. Oleh karena itu, pengujian mediasi dengan uji Sobel hanya dilakukan jika terdapat pengaruh yang signifikan dari CSRD terhadap reputasi dan reputasi terhadap ROA. Rumus uji Sobel adalah sebagai berikut:

Keterangan:

$$
S a b=\sqrt{b^{2} S a^{2}+a^{2} S b^{2}+S a^{2} S b^{2}}
$$

$\begin{array}{rlrl}\mathrm{Sab}= & \text { Besarnya standar eror dari pengaruh } \\ & \text { tidak langsung } \\ \mathrm{a} & =\begin{array}{l}\text { Jalur variabel independen dengan } \\ \text { variabel mediasi }\end{array} \\ \mathrm{b} & =\text { Jalur variabel mediasi dengan } \\ & \text { variabel dependen } \\ \mathrm{Sa} & = & \text { Standar eror koefisien a } \\ \mathrm{Sb} & = & \text { Standar eror koefisien } \mathrm{b}\end{array}$

\section{Perbandingan Luas CSRD oleh Bank di Indonesia, Singapura, dan Thailand}

Analisis data dalam penelitian ini menemukan bahwa ada perbedaan luas pengungkapan CSR (CSRD) oleh bank-bank yang terdaftar di Bursa Efek Indonesia (BEI), Bursa Efek Singapura (BES), dan Bursa Efek Thailand (BET) pada tahun 2017. Penelitian ini uga menemukan bahwa ada perbedaan CSRD di Indonesia dengan Singapura dan Thailand, dan o,ofhailand. Hasil tersebut belum sesuai dengan teori stakeholders dan teori signalling. dilind,dasikan belum memenuhi tuntutan stakeholders untuk memperluas informasi CSRnya.

Hasil penelitian ini sesuai dengan Loh et al. (2016) serta Rahmawati dan Budiwati (2018) yang menemukan bahwa terdapat perbedaan CSRD dalam kategori lingkungan di Indonesia dan Thailand. Perbedaan CSRD terutama dalam kategori lingkungan dapat terjadi karena adanya perbedaan regulasi, kesadaran perusahaan, atau budaya dalam masyarakat terkait pemeliharaan lingkungan. Karena ketiga negara telah mewajibkan pengungkapan CSR dan Indonesia sendiri telah memiliki regulasi terkait pemeliharaan lingkungan untuk bank maupun perusahaan sebagai debiturnya, maka perbedaan CSRD di Indonesia diindikasikan berasal dari rendahnya kesadaran perusahaan atau budaya dalam masyarakat untuk mengelola lingkungan dengan baik. Hasil penelitian ini sesuai dengan Loh et al. (2016) serta Supriyono dan Suhardjanto (2013) yang menemukan bahwa CSRD dalam kategori sosial oleh perusahaan di Indonesia lebih rendah daripada di Thailand. Sebaliknya, hasil penelitian ini tidak sesuai dengan Chapple dan Moon (2005) yang tidak menemukan adanya perbedaan CSRD di Indonesia dan Thailand.

\section{Pengaruh Luas CSRD terhadap Reputasi Bank}

Analisis data dalam penelitian ini menemukan bahwa tidak ada pengaruh yang signifikan dari luas pengungkapan CSR (CSRD) terhadap reputasi bank (Tobin's Q). Hampir semua bank di ketiga negara telah melaporkan 
CSR dalam laporan tahunannya. Akan tetapi, bank-bank di Indonesia diketahui memiliki CSRD dalam kategori lingkungan yang relatif sangat rendah dibandingkan dengan Singapura dan Thailand. Hal tersebut tidak sesuai dengan teori signalling karena bank seharusnya berusaha untuk mengurangi asimetri informasinya. Oleh karena itu, dapat diindikasikan bahwa bank-bank di Indonesia masih membentuk asimetri informasi sehingga investor yang menerapkan green economy di ketiga negara tidak dapat mendukung dan memprioritaskan pembelian saham pada bankbank dengan CSRD terutama dalam kategori lingkungan yang lebih baik.

Hasil penelitian ini sesuai dengan penelitian sebelumnya oleh Saeednia dan Sohani (2013) yang menemukan bahwa CSR tidak berpengaruh langsung terhadap reputasi, melainkan melalui variabel mediasi kepuasan konsumen pada Bank Saderat Iran. Oleh karena itu, dapat diindikasikan juga bahwa terdapat variabel mediasi seperti persepsi investor terhadap CSR yang dapat memengaruhi reputasi (Tobin's Q). Persepsi investor penting untuk diketahui karena CSRD dapat berpengaruh negatif terhadap reputasi seperti arah regresinya dalam penelitian ini. Hal tersebut terjadi karena CSR dianggap membebani perusahaan dan mengurangi dividen kepada investor di Indonesia (Sari et al. 2016). Sebaliknya, hasil penelitian ini tidak sesuai dengan Sari et al. (2016) serta Kapita dan Suardana (2018) yang menemukan bahwa CSRD berpengaruh positif terhadap nilai atau reputasi perusahaan.

\section{Pengaruh Reputasi Bank terhadap Profitabilitas}

Analisis data dalam penelitian ini menemukan bahwa reputasi bank (Tobin's Q) mempunyai pengaruh yang positif dan signifikan terhadap profitabilitas (ROA) oleh bank-bank yang terdaftar di BEI, BES dan BET pada tahun 2017. Hasil tersebut sesuai dengan teori stakeholders yang menyatakan bahwa bank yang memenuhi tuntutan stakeholder untuk mempunyai reputasi yang baik akan mendapat dukungan dari stakeholder-nya tersebut melalui peningkatan kinerja keuangan seperti profitabilitas (ROA).

Hasil penelitian ini sesuai dengan penelitian sebelumnya yang dilakukan oleh Saeidi et al. (2015). Sebaliknya, hasil penelitian ini tidak sesuai dengan Taghian et al. (2015) yang menemukan bahwa reputasi tidak berpengaruh langsung terhadap kinerja keuangan perusahaan, melainkan melalui variabel pangsa pasar. Oleh karena itu, disimpulkan bahwa reputasi bank dapat berpengaruh langsung terhadap profitabilitas karena nasabah bank bersedia membayar premi atas produk bank yang memiliki reputasi baik tanpa harus diawali dengan peningkatan pangsa pasar atau dana pihak ketiga pada bank.

\section{Mediasi Reputasi Bank pada Pengaruh Luas CSRD terhadap Profitabilitas}

Analisis data dalam penelitian ini menemukan bahwa reputasi tidak dapat memediasi pengaruh luas pengungkapan CSR (CSRD) terhadap profitabilitas (ROA) oleh bankbank yang terdaftar di BEI, BES, dan BET pada tahun 2017. Mediasi reputasi tidak terjadi karena tidak adanya pengaruh yang signifikan dari CSRD terhadap reputasi (Tobin's Q). Hasil tersebut tidak sesuai dengan teori stakeholders dan signalling karena analisis data dalam penelitian ini mengindikasikan bahwa investor tidak merespons CSRD oleh bank dengan mendukungnya melalui pembelian saham yang dapat meningkatkan nilai atau reputasinya.

Hasil penelitian ini tidak sesuai dengan penelitian sebelumnya yang dilakukan oleh Galbreath dan Shum (2012) serta Saeidi et al. (2015) yang menemukan bahwa reputasi dapat memediasi secara langsung pengaruh CSR terhadap kinerja keuangan. Rendahnya CSRD di ketiga negara terutama oleh bank-bank di Indonesia dalam kategori lingkungan 
diindikasikan sebagai alasan tidak adanya respons investor terhadap luas pengungkapan CSR oleh bank. Investor dan calon investor mungkin tidak dapat menilai apakah suatu bank telah transparan dan bertanggung jawab atau tidak jika dibandingkan dengan pesaingnya karena bank-bank di ketiga negara terutama Indonesia tidak mengungkapkan CSRD dalam kategori lingkungan atau penerapan green banking-nya secara memadai. Hal tersebut mungkin disebabkan karena bank tidak berperan langsung terhadap krisis lingkungan yang terjadi di Indonesia sehingga kurang peduli terhadap hal tersebut. Selain itu, persepsi investor juga penting untuk diketahui karena CSRD dapat berpengaruh negatif terhadap reputasi seperti penelitian oleh Sari et al. (2016) dan arah regresinya dalam penelitian ini. Oleh karena itu, perbedaan persepsi investor di ketiga negara juga dapat menjadi alasan tidak adanya pengaruh CSRD terhadap reputasi.

\section{PENUTUP}

Berdasarkan hasil pengolahan data maka dapat diambil kesimpulan sebagai berikut:

1. Terdapat perbedaan luas pengungkapan CSR (CSRD) oleh bank-bank yang terdaftar di Bursa Efek Indonesia (BEI), Bursa Efek Singapura (BES), dan Bursa Efek Thailand (BET) pada tahun 2017;

2. Luas pengungkapan CSR (CSRD) tidak berpengaruh signifikan terhadap reputasi (Tobin's Q);

3. Reputasi bank berpengaruh positif dan signifikan terhadap profitabilitas (ROA);

4. Reputasi bank tidak memediasi pengaruh CSRD terhadap profitabilitas (ROA).
Berdasarkan pembahasan dan kesimpulan di atas, maka penelitian ini memiliki implikasi sebagai berikut:

1. Shareholders perlu memengaruhi bank untuk melakukan pengungkapan CSR yang lebih luas dalam kategori lingkungan dengan memberikan preferensi terhadap sahamnya;

2. Bank perlu untuk memperluas pengungkapan CSR-nya untuk mengurangi asimetri informasi yang masih ada terutama dalam kategori lingkungan; (3) pemerintah dapat menetapkan regulasi yang menuntut bank untuk lebih memperhatikan dan mengungkapkan dampak lingkungan dan sosial dari aktivitas bisnis bank dan debiturnya.

Penelitian ini memiliki beberapa keterbatasan antara lain sebagai berikut:

1. Nilai $R^{2}$ dalam model penelitian ini $(1,9 \%$ dan 18,3\%) masih sangat rendah. Oleh karena itu, penelitian selanjutnya dapat menambah variabel-variabel yang terkait lainnya, seperti kepuasan nasabah, persepsi investor, atau keunggulan kompetitif;

2. Pengukuran luas pengungkapan CSR (CSRD) dengan standar GRI 4 yang digunakan belum dapat mengukur semua pengungkapan CSR pada bank seperti penerapan green banking-nya. Penelitian selanjutnya dapat menambahkan GRI FSSD atau menggunakan indeks lain yang lebih komprehensif untuk mengukur hal tersebut. 


\section{REFERENCES:}

Aisyah, D. A. N. dan Pujiyono. 2016. Aspek Hukum Penerapan Green Banking dalam Kegiatan Kredit di PT. Bank Negara Indonesia (Persero) Tbk. Privat Law, 4(2).

Allen, C. dan S. Clouth. 2012. A guidebook to the Green Economy. New York: United Nations Division for Sustainable Development.

Ali, Md. R., Md. S. Mahmud, dan Lima, R. P. 2016. Analyzing Tobin's Q Ratio of Banking Industry of Bangladesh: A Comprehensive Guideline for Investors. Asian Business Consortium, 6(2), 85-90.

Bahl, S. 2012. Green Banking - The New Strategic Imperative. Asian Journal of Research in Business Economics and Management, 2(2), 176-185.

Bank Negara Indonesia. 2017. Laporan Keberlanjutan 2017. Jakarta: BNI.

Brigham, E. F. dan J. F. Houston. 2010. Dasar-dasar Manajemen Keuangan (Edisi 11). Jakarta: Salemba Empat.

Chapple, W. dan J. Moon. 2005. Corporate Social Responsibility (CSR) in Asia: A Seven-Country Study of CSR Web Site Reporting. Business \& Society, 44, 414-441.

Chrysolite, H., R. Julian, J. Chitra, dan M. Ge. 2017. Evaluating Indonesia's Progress on its Climate Commitments. Diunduh tanggal 2 Juni 2019, http://www.wri.org.

Connelly, B. L., S. T. Certo, R. D. Ireland, dan C. R. Reutzel. 2011. Signaling theory: A review and assessment. Journal of Management, 37(1), 39-67.

Direktorat Lingkungan Hidup. 2013. Kumpulan Pemikiran Pengembangan Green Economy di Indonesia (Tahun 2010-2012). Jakarta: Direktorat Lingkungan Hidup.

European Commission. 2017. Corporate Social Responsibility \& Responsible Business Conduct. Diunduh tanggal 2 Juni 2019, http://www.ec.europa.eu.

Fombrun, C., dan C. van Riel. 1997. The Reputational Landscape. Corporate Reputation Review, 1(2), 5-13.

Freeman, R. E., J. Harrison, A. Hicks, B. Parmar, dan S. de Colle. 2010. Stakeholder Theory: The State of the Art. New York: Cambridge University Press.

Galbreath, J., dan P. Shum. 2012. Do costumer satisfaction and reputation mediate the CSR-FP link? Evidence from Australia. Australian Journal of Management, 37, 211-229.

Global Reporting Initiative. 2019. About Sustainibility Reporting. Diunduh tanggal 2 Juni 2019, http://www.globalreporting.org.

Hardjana, A. A. 2008. Komunikasi dalam Manajemen Reputasi Korporasi. Jurnal Ilmu Komunikasi, 5(1), 1-24.

Helm, S. 2007. The Role of Corporate Reputation in Determining Investor Satisfaction and Loyalty. Corporate Reputation Review, 10(1), 22-37.

Kapita, N. M. Y., dan K. A. Suardana. 2018. Pengaruh Pengungkapan Corporate Social Responsibility dan Good Corporate Governance Pada Reputasi Perusahaan Manufaktur. E-Jurnal Akuntansi Universitas Udayana, 24, 1190-1219.

Kasikornbank. 2017. Kasikornthai Sustainibility Report 2017. Diunduh tanggal 2 Juni 2019, http://www.kasikornbank.com.

Kementerian Lingkungan Hidup. 2014. Peningkatan Peran Lembaga Jasa Keuangan Dalam Perlindungan dan Pengelolaan Lingkungan Hidup Melalui Pengembangan Jasa Keuangan Berkelanjutan. Diunduh tanggal 2 Juni 2019, http://www.menlh.go.id.

KPMG International. 2015. Currents of change: The KPMG Survey of Corporate Responsibility Reporting 2015. Switzerland: KPMG.

2017. The Road Ahead: The KPMG Survey of Corporate Responsibility Reporting 2017. Switzerland: KPMG.

Loh, L., N. T. P. Thao, I. Sim, T. Thomas, dan W. Yu. 2016. Sustainability Reporting in ASEAN. Singapore: National University of Singapore.

Paino, C. 2015. Bagaimana Cara Perbankan Menilai Perkebunan Sawit di Sulawesi Tengah? Diunduh tanggal 2 Juni 2019, dari http://www.mongabay.co.id. 
Perbanas. 2009. Seminar Nasional: Peran Perbankan Dalam Mendukung Ekonomi Hijau Menuju Praktek Perbankan Berwawasan Lingkungan. Diunduh tanggal 2 Juni 2019, dari http://www.perbanas.id.

Philp, K., J. Stampe, N. Tan, L. S. Ping, L. Loh, dan R. Wynne. 2018. WWF Sustainable Banking Report Update 2018. Switzerland: WWF.

Rahmawati, S., dan C. Budiwati. 2018. Karakteristik Perusahaan, ISO 14001, dan Pengungkapan Lingkungan: Studi Komparatif di Indonesia dan Thailand. Jurnal Akuntansi Dan Bisnis, 18, 74-87.

Saeidi, S. P., S. Sofian, P. Saeidi, S. P. Saeidi, dan S. A. Saaeidi. 2015. How does corporate social responsibility contribute to firm financial performance? The mediating role of competitive advantage, reputation, and customer satisfaction. Journal of Business Research, 68(2), 341-350.

Sari, W. A., S. R. Handayani, dan N. F. Nuzula. 2016. Pengaruh Pengungkapan Corporate Social Responsibility terhadap Kinerja Keuangan dan Nilai Perusahaan (Studi Komparatif pada Perusahaan Multinasional yang Terdaftar di Bursa Efek Indonesia dan Bursa Malaysia Tahun 2012-2015). Jurnal Administrasi Bisnis, 39(2), 74-83.

Sari, P.Y., dan D. Priantinah. 2018. Pengaruh Kinerja Keuangan dan Corporate Social Responsibility (CSR) terhadap Nilai Perusahaan pada Bank yang Terdaftar di Bursa Efek Indonesia Periode 2011-2015. Jurnal Nominal, 7(1), 111-125.

Setiawan, A. 2017. Analisis Pengaruh Tingkat Kesehatan Bank terhadap Return On Asset. Jurnal Analisa Akuntansi Dan Perpajakan, 1(2), 130-152.

Shen, C. H., Wu, M. W., Chen, T.H., dan Fang, H. 2016. To engage or not to engage in corporate social responsibility: Empirical evidence from global banking sector. Economic Modelling. 55, 207-225.

Sukamulja, S. 2005. Good Corporate Governance di Sektor Keuangan: Dampak Good Corporate Governance Terhadap Kinerja Keuangan. Jurnal Akuntansi. 8 (1), 1-5.

Supriyono, E., dan D. Suhardjanto. 2013. Praktik pengungkapan sosial: studi komparatif di asia tenggara. Siasat Bisnis, 17(2), 187-207.

Taghian, M., C. D'Souza, dan M. J. Polonsky. 2015. A stakeholder approach to corporate social responsibility, reputation and business performance. Social Responsibility Journal, 11(2), 340-363.

Tan, C. K., dan E. Maulia. 2017. Indonesia and Malaysia Fire Back at EU in Palm Oil War. Diunduh tanggal 2 Juni 2019, dari http://www.asia.nikkei.com.

The Development Bank of Singapore. 2017. DBS Group Holding Ltd Annual Report 2017. Diunduh tanggal 2 Juni 2019, http://www.dbs.com.

The Jakarta Post. 2018. Producers Protest Supermarket Chain's Ban of Palm Oil Products. Diunduh tanggal 2 Juni 2019, dari http://www.thejakartapost.com.

Yadaf, R. S., Dash, S. S., Chakraborty, S., dan Kumar, M. 2018. Perceived CSR and Corporate Reputation: The Mediating Role of Employee Trust. The Journal for Decision Makers. 43(3), 139-151.

Venkataraman, S. 1999. Stakeholder Value Equilibration and The Entrepreneurial Process. Working Paper, University of Virginia. 
